\title{
Assessment of heritability and genetic advance for agronomic traits in durum wheat (Triticum durum Desf.)
}

\author{
Hassan NIKKHAHKOUCHAKSARAEI ${ }^{1}$, Hamlet MARTIROSYAN ${ }^{2}$
}

Received January 29, 2017; accepted July 08, 2017.

Delo je prispelo 29. januarja 2017, sprejeto 08. julija 2017.

\begin{abstract}
In order to evaluate the amount of heritability for desirable agronomic characteristics and the genetic progress associated with grain yield of durum wheat (Triticum durum Desf.), a split plot experiment was carried out with four replications during three cropping seasons (2009-2012). Three sowing dates (as environmental factor) and six durum wheat varieties (as genotypic factor) were considered as main and sub factors respectively. Analysis of variance showed interaction effects between genotypes and environments in days to ripening, plant height, spike length, number of grains per spike, number of spikes per unit area, grain mass and grain yield. The grain yield showed the highest positive correlation with number of grains per spike also grain mass $(91 \%$ and $85 \%$, respectively). A relatively high heritability of these traits ( $82.1 \%$ and $82.2 \%$, respectively) suggests that their genetic improvement is possible. The maximum genetic gain (19.6\%) was observed for grain mass, indicating this trait should be a very important indicator for durum wheat breeders, although the climatic effects should not be ignored.
\end{abstract}

Key words: durum wheat; grain yield; plant genetics; yield components

\section{IZVLEČEK \\ OVREDNOTENJE DEDNOSTI IN GENETSKE PREDNOSTI AGRONOMSKIH LASTNOSTI TRDE PŠENICE (Triticum durum Desf.)}

Z namenom ovrednotenja dednosti željenih agrononmskih lastnosti in genetskih procesov povezanih s pridelkom zrnja trde pšenice (Triticum durum Desf.) je bil izveden poskus $\mathrm{z}$ deljenkami s štirimi ponovitvami v rastnih sezonah 20092012. Tri datumi setve kot okoljski dejavniki in šest sort trde pšenice kot genetski dejavnik so bili uporabljeni kot glavni in podrejeni dejavniki. Analiza variance je pokazala interakcijske učinke med genotipi in okoljem $\mathrm{v}$ dnevih do zrelosti, višini rastlin, dolžini klasov, številu zrna na klas, številu klasov na enoto površine, masi zrn in pridelku zrnja. Pridelek zrnja je pokazal največjo pozitivno korelacijo s številom zrn na klas in maso zrnja, $91 \%$ in $85 \%$. Relativno velika dednost teh lastnosti, $82.1 \%$ in $82.2 \%$ nakazuje, da je možno njuno genetsko izboljšanje. Največja genetska pridobitev (19.6\%) je bila opažena pri masi zrnja, kar nakazuje, da bi morala biti ta lastnost zelo pomemben kazalnik za žlahtnitelje trde pšenice, čeprav tudi podnebni dejavniki ne bi smeli biti zanemarjeni.

Ključne besede: trda pšenica; pridelek zrnja; rastlinska genetika; komponente pridelka

\section{INTRODUCTION}

Durum wheat (Triticum durum Desf.) is cultivated on 21 million hectares, about $10 \%$ of all cultivated areas in the world. Durum wheat is an important and popular crop in the Mediterranean region and is used for food products as couscous, bulgur, and pasta (Gisslen, 2001). Durum wheat genotypes had shown better adaptation to varying environments than common wheat ( $T$. aestivum L.) (Khazaei et al., 2013). So, selection of the stable durum wheat genotypes for achieving both high grain yield and good quality is very important. It is important to use appropriate selection method and selection intensity for traits of interest, proper statistical assessment of genetic variation, the magnitude of heritability (usually represented by $\mathrm{h}^{2}$ ), genetic coefficient of variation, and response to selection.

1 Department of Agronomy and Plant Breeding, Qaemshahr Branch, Islamic Azad University, Qaemshahr, Iran; * Corresponding author: hsnnikkhah@yahoo.com

2 Department of Plant Cultivation, Armenian National Agrarian University, Yerevan, Armenia

This article is part of the Ph.D. thesis entitled « Influence of some agro technical measures on the productivity of durum wheat (Triticum durum Desf.) varieties (under the conditions of Mazandaran province of Iran) », issued by Hassan Nikkhahkouchaksaraei, supervisor Assist. Prof. Hamlet Martirosyan, $\mathrm{Ph}$. D. 
Genetic variability is an important factor in hybridization program for producing high yielding progenies. The effective selection depends on the amount of genetic variability and amount of heritability indices (Heidari, 2010).

For having a good response to selection, high genetic variation and high heritability are needed (Shukla et al., 2006). There is a direct relationship between heritability and response to selection which is referred to as genetic progress. The expectation of a response to selection is called genetic advance (G.A.). High genetic advance coupled with high heritability estimate offers the best effective condition for selection (Larik et al., 2000). Therefore, genetic advance is an important indicator associated with selection that aids plant breeder in his work (Shukla et al., 2006; Memon et al., 2005). High genetic variation for traits under selection as well as high heritability, are crucial for having good response to selection (Shukla et al., 2006). Manal (2009) reported high heritability accompanied by high genetic advance for spike length and 1000 grain-mass in his study of heritability and genetic advance of yield traits in common wheat (T. aestivum) under drought condition. This fact suggests that selection should lead to a fast genetic improvement of trait. The purpose of this study was to identify the traits which can be used as selection markers and can also help to predict the grain yield of durum wheat.

\section{MATERIALS AND METHODS}

The experiments were conducted during three crop seasons (2009-2012), at the experimental field of the Islamic Azad University, Qaemshahr Branch, Mazandaran Province of Iran $\left(36^{\circ} 30^{\prime} \mathrm{N}, 52^{\circ} 48^{\prime} \mathrm{E}\right.$, $28 \mathrm{~m}$ above sea level). The experiments were designed as split-plots based on randomized complete block design with four replicates. Three sowing dates (as environmental conditions) were 25 October, 25 November and 25 December and were randomized as main plots. Six durum wheat genotypes ('Yavaros', 'Tarro-3', 'Shwa/Mald', 'Stork', 'Behrang' and 'Syrian-4') from different origin (CYMMIT and ICARDA) were used as subplots.

Each plot included fifteen rows $5 \mathrm{~m}$ long and $0.18 \mathrm{~m}$ apart. The seed rate was 500 viable seeds per one square meter. Based on soil test, urea fertilizer $(46,0,0$; N. P. $\mathrm{K}$.) as source of nitrogen, and triple superphosphate fertilizer $(0,46,0 ;$ N. P. K.) as source of phosphorus were used. Herbicide, fungicide and insecticide were used as usual. The area of 3 square meters was harvested to estimate grain yield and related traits (including the number of days to ripening, plant height, spike length, number of grains per spike, number of spikes per square meter and grain mass) at when plants were mature.

Analysis of variance and combined analysis of variance (Steel and Torrie, 1980) were conducted on data by using the statistical SAS program (SAS Institute, 2008), in according to following statistical model. Years with random effect as well as treatments and sowing dates with fixed effects had considered in this model (Yazdi Samadi et al., 1997). Mean comparisons by using Duncan's Multiple Range Test.

$X_{i j k l}=\mu+G_{i}+B_{i j k}+D_{k}+Y_{l}+G D_{i k}+G Y_{i l}+D Y_{k l}+$ $G D Y_{i k l}+E_{i j k l} \quad$ (Steel and Torrie, 1980)
Where, $X_{i j k l}$ is the amount of each trait in a plot. The mean of trait, the effect of genotype, the effect of repetition, the effect of sowing date, the effect of binary interaction (respectively, including the effect of genotype $\times$ sowing date, genotype $\times$ year, planting date $x$ year), the effect of triplet interaction (genotype $\times$ sowing date $x$ year) and residual effect or experimental error, have been shown from left to right, respectively.

Phenotypic coefficient of variation $\left(\delta_{p}^{2}\right)$ depends on genetic variation $\left(\delta_{\mathrm{g}}^{2}\right)$, environmental variation $\left(\delta_{\mathrm{e}}^{2}\right)$ and their interactions.

$\delta_{p}^{2}=\delta_{g}^{2}+\delta_{g y}^{2}+\delta_{g d}^{2}+\delta_{g y d}^{2}+\delta_{e}^{2}$

$\delta_{g d}^{2}=(M 5-M 6-M 7+M 8) / r d y$

$\delta_{g y}^{2^{g}}=(M 7-M 8+M 9) / r d$

$\delta_{g d}^{2}=(M 7-M 8+M 9) / r y$

$\delta^{2}{ }^{2 d}=(M 9-M 8) / r$

$\delta^{2}{ }_{e}=M 9$

Also the following formulas are used for calculating the coefficients of variation (Burton, 1952).

G.CV. $=\left(\sqrt{ } \delta^{2}{ }_{g} / \bar{Y}\right) \times 100$

P.CV. $=\left(\sqrt{ } \delta_{p}^{2} / \bar{Y}\right) \times 100$

E.CV. $=\left(\sqrt{ } \delta_{e}^{2} / \bar{Y}\right) \times 100$

P.C.V.; G.C.V. and E.C.V., were coefficient of variation of phenotypes, genotypes and environments, respectively. Also, $\bar{Y}$ was considered as a mean of trait. The following formula was used to predict the amount of broad sense heritability $\left(\mathrm{h}_{\mathrm{b}}^{2}\right)$ (Marwede et al., 2004).

$h_{b}^{2}=\left(\delta_{g}^{2} /\left[\left(\delta_{g}^{2}+\left(\delta_{e}^{2} / r y\right)+\left(\delta_{g y}^{2} / y\right)\right]\right.\right.$

where: $\mathrm{g}, \mathrm{r}, \mathrm{y}, \mathrm{d}, \delta_{\mathrm{g}}^{2}, \delta_{\mathrm{e}}^{2}, \delta_{\mathrm{g} \times \mathrm{e}}^{2}, \delta_{\mathrm{p}}^{2}$ and $\mathrm{h}_{\mathrm{b}}^{2}$ refer to the number of genotypes, number of repetitions, number of years of experiment, genotypic variance, environmental variance, the variance of genotype-environment interaction, phenotypic variance and broad sense 
heritability, respectively. Amount of $\mathrm{g}, \mathrm{r}$, y and $\mathrm{d}$ was 6 , 4,3 and 3 , respectively. The amount of variance $\left(\delta^{2}\right)$ was obtained base on mathematical expectancy factors (Table 1).

The following formula was used to estimate the average genetic improvement (Johnson et al., 1955).

Genetic gain (G.G.) $=K \times \delta_{p} \times h^{2}{ }_{b}$
In this study, selection intensity was calculated at $5 \%$ level.

$\mathrm{K}=2.06 \quad$ (Allard, 1960)

Also following formula was used to estimating the genetic advance of traits

G.A. $\%=($ G.A. $/ \bar{Y}) \times 100$

\section{RESULTS AND DISCUSSION}

The analysis of variance (Table 1) showed a substantial variation in grain yield for years, sowing dates, and genotypes. A significant interaction effect was found between sowing date and amount of traits $(\mathrm{P} \leq 1 \%)$. This result confirms the reports of Rahman et al. (2009). Also a significant interaction was established between genotypes and environment effects. It shows that, in addition to genotypic factor (genetic structure), environmental factors influenced the studied traits too. So, farm management has to consider the date set of sowing for each durum wheat genotype (Table 1).

Table 1: Combined analysis of variance for some durum wheat traits

\begin{tabular}{|c|c|c|c|c|c|c|c|c|c|}
\hline \multirow[b]{2}{*}{$\begin{array}{c}\text { Source of } \\
\text { variation }\end{array}$} & \multirow[b]{2}{*}{ D.F. } & \multicolumn{8}{|c|}{ Mean Square } \\
\hline & & & $\begin{array}{l}\text { Days to } \\
\text { ripening }\end{array}$ & $\begin{array}{l}\text { Plant } \\
\text { height } \\
(\mathrm{cm})\end{array}$ & $\begin{array}{l}\text { Length } \\
\text { of spike } \\
(\mathrm{cm})\end{array}$ & $\begin{array}{c}\text { Grains } \\
\text { per Spike }\end{array}$ & $\begin{array}{l}\text { Spikes per } \\
\mathrm{m}^{2}\end{array}$ & $\begin{array}{c}\text { Mass of } \\
1000 \\
\text { grains }(\mathrm{g})\end{array}$ & $\begin{array}{c}\text { Grain } \\
\text { yield } \\
(1000 \mathrm{~kg} \\
\left.\text { ha }^{-1}\right)\end{array}$ \\
\hline Sowing date(D) & 2 & M1 & $41586.77 * *$ & $1714.66^{* *}$ & $14.78 * *$ & $191.77 * *$ & $10924.3 * *$ & $350.93 * *$ & $19.21 * *$ \\
\hline Year $(Y)$ & 2 & M2 & $0.02^{\mathrm{ns}}$ & $0.16^{\mathrm{ns}}$ & $99.11 * *$ & $5.87 * *$ & $1804.8 * *$ & $0.23 *$ & $0.03^{\mathrm{ns}}$ \\
\hline $\mathrm{Y} \times \mathrm{D}$ & 4 & M3 & $0.06^{\mathrm{ns}}$ & $0.57^{\mathrm{ns}}$ & $0.41^{\mathrm{ns}}$ & $1.90^{\mathrm{ns}}$ & $115.1 * *$ & $0.05^{\mathrm{ns}}$ & $0.01^{\mathrm{ns}}$ \\
\hline $\mathrm{R}(\mathrm{Y} \times \mathrm{D})$ & 27 & M4 & $0.03^{\mathrm{ns}}$ & $0.56^{\mathrm{ns}}$ & $0.04^{\mathrm{ns}}$ & $1.16^{\mathrm{ns}}$ & $10.1^{\mathrm{ns}}$ & $0.08^{\mathrm{ns}}$ & $0.02^{\mathrm{ns}}$ \\
\hline Cultivars (G) & 5 & M5 & $29.97 * *$ & $1818.82 * *$ & $8.22 * *$ & $441.05 * *$ & $6938.0 *$ & $474.99 * *$ & $26.66 * *$ \\
\hline $\mathrm{G} \times \mathrm{D}$ & 10 & M6 & $18.11 * *$ & $114.43 * *$ & $0.28 * *$ & $16.95 * *$ & $2059.8 * *$ & $20.19 * *$ & $0.65 * *$ \\
\hline $\mathrm{G} \times \mathrm{Y}$ & 10 & M7 & $0.05^{*}$ & $1.14^{\mathrm{ns}}$ & $1.79 * *$ & $1.52^{\mathrm{ns}}$ & $227.0 * *$ & $0.18 * *$ & $0.02^{\mathrm{ns}}$ \\
\hline $\mathrm{G} \times \mathrm{Y} \times \mathrm{D}$ & 20 & M8 & $0.05 *$ & $0.83^{\mathrm{ns}}$ & $0.25 * *$ & $1.57 *$ & $136.7 * *$ & $0.14 * *$ & $0.02^{\mathrm{ns}}$ \\
\hline Error & 90 & M9 & 0.02 & 0.66 & 0.09 & 0.95 & 8.0 & 0.06 & 0.01 \\
\hline
\end{tabular}

$\mathrm{ns}=$ non-significant, $*$ significant in $5 \%, * *$ significant in $1 \%$

The grain yield amount in early sowing (25 October) was $3.8 \%((4225-4062) / 4225)$ as well as in late sowing (25 December) was $21.8 \%((4225$ - 3302) /
4225) lower than in optimum sowing date (25 November), according to data in table 2.

Table 2: Mean comparisons of effect of sowing dates on grain yield of wheat varieties

\begin{tabular}{lcccccccc}
\hline Sowing date & \multicolumn{7}{c}{ Grain yield $\left(\mathrm{kg} \mathrm{h}^{-1}\right)$} \\
\cline { 2 - 8 } & Yavaros & Tarro-3 & Shwa/Mald & Stork & Behrang & Syrian-4 & Zardak & Average \\
\hline 25 October & $3997 \mathrm{~b}$ & $4099 \mathrm{a}$ & $3924 \mathrm{a}$ & $5172 \mathrm{a}$ & $5083 \mathrm{~b}$ & $3833 \mathrm{~b}$ & $2324 \mathrm{~b}$ & $4062^{\mathrm{b}}$ \\
25 November & $4353 \mathrm{a}$ & $4269 \mathrm{a}$ & $3772 \mathrm{a}$ & $5163 \mathrm{a}$ & $5315 \mathrm{a}$ & $4149 \mathrm{a}$ & $2553 \mathrm{a}$ & $4225^{\mathrm{a}}$ \\
25 December & $3066 \mathrm{c}$ & $3743 \mathrm{~b}$ & $3293 \mathrm{~b}$ & $3654 \mathrm{~b}$ & $4414 \mathrm{c}$ & $3113 \mathrm{c}$ & $1833 \mathrm{c}$ & $3302^{\mathrm{c}}$ \\
\hline
\end{tabular}

a, b, c Means within columns indicated by the same letter are not significantly different at $\mathrm{P} \leq 0.01$ according to Duncan's multiple range test. 
Previous studies confirmed the importance of considering appropriate sowing date in each region (Rahman et al., 2009). The management should choose the optimal sowing date because it is crucial in order to optimize grain yield in such an environment (Radmehr et al., 2003 and Turner, 2004).

Bassu et al. (2009) and Bannayan et al. (2013) reported increasing of yield in early sowing and also its reduction in late sowing. One of the advantages of late sowing is the reduction of frost risk at anthesis. However the delay in sowing does not only affect the yield but also other aspects of growth and development of wheat, as well as yield components. It is generally related to reduced grain mass, number of grains per spike, number of spikes per plant, number of spikes per unit area, harvest index, and leaf area index (Radmehr et al., 2003). Accurate knowledge of the sowing time of any particular variety at a particular location is critical to achieve high grain yield (Andarzian, 2015). The highest and the lowest coefficients of phenotypic variation were determined for the number of spikes $(84 \%)$ and the number of days to grain maturity $(0.4 \%)$, respectively; while the highest heritabilities were calculated for grain mass, number of grains per spike and plant height (87.7 \%, 82.2\% and 82.1\%, respectively) (Table 3).

Table 3: Components of genotypic variation, phenotypic variation, heritability and genetic advance for studied traits

\begin{tabular}{cccccccccc} 
Characters & Range & Mean \pm SD & $\begin{array}{c}\mathrm{GCV} \\
(\%)\end{array}$ & $\begin{array}{c}\mathrm{PCV} \\
(\%)\end{array}$ & $\delta_{\mathrm{g}}^{2}$ & $\delta_{\mathrm{p}}^{2}$ & $\begin{array}{c}\mathrm{h}_{\mathrm{b}}^{2} \\
(\%)\end{array}$ & $\begin{array}{c}\text { Genetic } \\
\text { Advance } \\
(\%)\end{array}$ & $\begin{array}{c}\text { Genetic Gain } \\
(\%)\end{array}$ \\
\hline $\begin{array}{c}\text { Days to } \\
\text { ripening }\end{array}$ & $192.0-242.0$ & $218.5 \pm 18.2$ & 0.2 & 0.4 & 0.3 & 0.8 & 38.3 & 0.7 & 0.3 \\
$\begin{array}{c}\text { Plant height } \\
(\mathrm{cm})\end{array}$ & $77.2-115.0$ & $92.22 \pm 8.12$ & 7.4 & 8.2 & 47.3 & 57.6 & 82.1 & 12.8 & 13.9 \\
$\begin{array}{c}\text { Length of spike } \\
(\mathrm{cm})\end{array}$ & $5.2-10.6$ & $7.7 \pm 1.2$ & 5.5 & 8.8 & 0.2 & 0.4 & 39.1 & 0.5 & 7.1 \\
$\begin{array}{c}\text { Grains per spike } \\
\text { Spikes in m }{ }^{2}\end{array}$ & $17.1-35.61$ & $26.8 \pm 3.8$ & 12.8 & 14.1 & 11.7 & 14.3 & 82.2 & 1.5 & 5.6 \\
$\begin{array}{c}\text { Mass of 1000 } \\
\text { grains (g) }\end{array}$ & $23.0-40.7$ & $407.2 \pm 19.6$ & 32.6 & 84.0 & 132.9 & 342.3 & 38.8 & 14.7 & 3.6 \\
\hline SD: & $34.8 \pm 3.9$ & 10.2 & 10.8 & 12.6 & 14.3 & 87.7 & 6.8 & 19.6 \\
\hline
\end{tabular}

SD: standard deviation; GCV: genetic coefficient of variation; PCV: phenotypic coefficient of variation; $\delta_{\mathrm{g}}^{2}=$ genotypic variance; $\delta_{\mathrm{p}}^{2}=$ phenotypic variance; $\mathrm{h}_{\mathrm{b}}^{2}=$ broad sense heritability

Coefficients of correlation were calculated using the method of Snedecor and Cochran (1989) with n-2 degrees of freedom at 5 and 1 percent levels. The highest positive correlation coefficient were determined between grain yield and number of grains per spike, grain mass, number of spikes per unit area and days to ripening (Table 4). Also, a significant negative correlation was found between plant height and grain yield and thus confirming the finding of Siahpoosh et al.
(2003) and Rashidi et al. (2013) reports. They also reported a positive correlation between plant height and grain yield in some of their investigations. The plant height, therefore, need not to be considered as an indicator for selection of genotypes with high grain yield. Statistical analysis for agronomic traits in durum wheat showed that grain yield depended on the number of grains per spike and grain mass $(\mathrm{r}=0.91 * *$ and $\mathrm{r}=$ $0.85^{* *}$, respectively) (Table 4 ).

Table 4: Correlation coefficient of studied durum wheat traits

\begin{tabular}{|c|c|c|c|c|c|c|}
\hline & $\begin{array}{l}\text { Days to } \\
\text { ripening }\end{array}$ & $\begin{array}{c}\text { Plant height } \\
(\mathrm{cm})\end{array}$ & $\begin{array}{l}\text { Length of } \\
\text { spike }(\mathrm{cm}) \\
\end{array}$ & $\begin{array}{c}\text { Grains per } \\
\text { spike }\end{array}$ & $\begin{array}{l}\text { Spikes } \\
\text { per } \mathrm{m}^{2} \\
\end{array}$ & $\begin{array}{c}\text { Mass of } 1000 \\
\text { grains }(\mathrm{g})\end{array}$ \\
\hline Days to ripening & 1 & & & & & \\
\hline Plant height & $0.58 * *$ & 1 & & & & \\
\hline Length of spike & $0.15 * *$ & $0.55^{* *}$ & 1 & & & \\
\hline Grains per spike & $0.14 * *$ & $-0.47 * *$ & $-0.08^{\mathrm{ns}}$ & 1 & & \\
\hline Spikes in $\mathrm{m}^{2}$ & $0.30 * *$ & $-0.17 * *$ & $0.22 * *$ & $0.36 * *$ & 1 & \\
\hline Mass of 1000 grains & $0.39 * *$ & $-0.42 * *$ & $-0.03^{\mathrm{ns}}$ & $0.63 * *$ & $0.40 * *$ & 1 \\
\hline Grain yield & $0.34 * *$ & $-0.52 * *$ & $-0.01^{\mathrm{ns}}$ & $0.91 * *$ & $0.57 * *$ & $0.85^{* *}$ \\
\hline
\end{tabular}

ns $=$ non-significant, $* *$ significant in $1 \%$

,+- : positive and negative correlation 
The results of this study conforms Evans (1993), Satorre and Slafer (1999) reports. They reported that the increase of number of grains per spike is the most important indicator for high grain yield. In this way, this trait can be considered as a reliable indicator for selection of genotypes with higher grain yield. High grain mass is also an important indicator in selection of superior genotypes. Therefore, selection of genotypes based on a higher number of grains per spike and higher grain mass will improve the selection efficiency for more grain yield.

\section{CONCLUSIONS}

High and significant positive correlation between grain yield and number of grains per spike, and grain mass in durum wheat suggests that these traits can be considered as two important factors in selection for genotypes with higher grain yield. Because of high heritability of these traits, genetic improvement of grain yield in durum wheat is possible. The maximum genetic gain (19.6\%) determined for grain mass suggests that this trait can be a very important indicator in durum wheat breeding, although the environment effects should not be ignored.

\section{REFERENCES}

Allard, R. W. (1960). Principles of plant breeding. John Wiley and Sons Inc., New York.

Andarzian, B., Hoogenboom, G, Bannayan, M., Shirali, M., Andarzian, B. (2015). Determining optimum sowing date of wheat using CSM-CERES-Wheat model. Journal of the Saudi society of agricultural sciences, 14(2), 189-199. doi:10.1016/j.jssas.2014.04.004

Bannayan, M., Crout, N. M. J., Hoogenboom, G. (2003). Application of the CERES-Wheat model for within-season prediction of wheat yield in United Kingdom. Agronomy Journal, 95, 114-125. doi:10.2134/agronj2003.0114

Bassu, S., Asseng, A., Motzo, R., Giunta, F. (2009). Optimising sowing date of durum wheat in a variable Mediterranean environment. Field Crops Research, 111, 109-118. doi:10.1016/j.fcr.2008.11.002

Burton, G. W. (1952). Quantitative inheritance in grasses. $6^{\text {th }}$ Int. Grassland Congress, 1, 277-283.

Evans, L. T. (1993). Crop Evolution, Adaptation and Yield. Cambridge University Press, U. K.

Gisslen, W. (2001). Professional baking, John Wiley \& Sons.

Heidari, B. (2010). Genetic variation and genetic gain from selection in bread wheat. Electronic Journal of Crop Production, 3(3), 239-246. (In Persian with English abstract).

Johnson, H. W., Robinson, H. F., Comstock, R. E. (1955). Estimate of genetic and environmental variability in soybean. Agronomy Journal, 47, 314318. doi: 10.2134/agronj1955.0002196200470

Khazaei, M., Tadayyon, A., Houshmand, S. (2013). Heritability and relationship among durum wheat quality traits using a recombinant inbred lines population. Journal of Crop production and Processing, 3(9), 123-136. (In Persian with English abstract).

Larik, A. S., Malik, S. I., Kakar, A. A., Naz, M. A. (2000). Assessment of heritability and genetic advance for yield components in $G$. hirsutum. Science Khyber, 13, 39-44.

Manal, H. Eid. (2009). Estimation of heritability and genetic advance of yield traits in wheat (Triticum aestivum L.) under drought condition. International Journal of Genetics and Molecular Biology, 1(7), 115-120.

Marwede, V., Schierholt, A., Mollers, C., Becker, H. C. (2004). Genotype $\times$ environment interactions and heritability of tocopherol contents in canola. Crop Science, $\quad 44, \quad 728-731$. doi:10.2135/cropsci2004.7280

Memon, S. M., Ansari, B. A., Balouch, M. Z. (2005). Estimation of genetic variation for agroeconomic traits in spring wheat (Triticum aestivum L.). Indian Journal of Plant Science, 4, 171-175.

Radmehr, M., Ayeneh, G. A., Mamghani, R. (2003). Responses of late, medium and early maturity bread wheat genotypes to different sowing date. I. Effect of sowing date on phenological, morphological, and grain yield of four bread wheat genotypes. Iran Journal of Seed Sapling, 21(2), 175-189 (In Persian with English abstract)

Rahman, M. M., Akbar, H., Hakim, M. A., Kabir, M. R., Shah, M. M. R. (2009). Performance of wheat genotypes under optimum and late sowing condition. International of Journal Sustain Crop Production, 4(6), 34-39. 
Rashidi, V., Reihani Mehr, S., Chalabi Yani, S. (2013). Assignment of the relations among traits and regression and path analyses of grain yield in promising lines and cultivars of temperate and cold regions bread wheat. New Finding in Agriculture, 8(1), 17-26. (In Persian with English abstract).

SAS INSTITUTE INC. (2008). SAS/STAT User's guide, version 9.02. SAS Institute Inc., Cary, NC, USA

Satorre, E. H., Slafer, G. A. (eds.) (1999). Wheat, ecology and physiology of yield determination. Food Product Press, NY.

Shukla, S., Bhargava, A., Chatterjeee, A., Sivastava, A., Singh, S. P. (2006). Genetic variability in vegetable amaranth (Amaranthus tricolor L.) for foliage yield and its contributing traits over successive cuttings and years. Euphytica, 151, 103-110. doi:10.1007/s10681-006-9134-3

Siahpoosh, M. R., Imam, I., Saeidi, E. (2003). Genotypic variation, heritability, genotypic and phenotypic correlation coefficients of grain yield, its components and some morpho-physiological characters in bread wheat (Triticum aestivum L.).
Iranian Journal of Crop Sciences, 5(2), 86-98 (In Persian with English abstract).

Snedecor, G. W., Cochran, W. G. (1989). Statistical Methods, Eighth Edition, Iowa State University Press.

Steel, R. G. D., Torri, J. H. (1980). Principles and procedures of statistics. Mc Graw-Hill companies, USA.

Taleei, A., Bahram-nejad, B. (2003). A Study of Relationship Between Yield and Its' Components in Landrace Populations of Wheat from Western Parts of Iran Using Multivariate Analysis. Iranian, Journal of Agricultural Sciences, 34(4), 949-959. (In Persian with English abstract).

Turner, N. C. (2004). Agronomic options for improving rainfall use efficiency of crops in dry-land farming systems. Journal of Experimental Botany, 55, 2413-2425. doi:10.1093/jxb/erh154

Yazdi Samadi, B., Rezaei, A., Valyzadeh, M. (1997). Statistical designs in agricultural research. Tehran university publications. Tehran, Iran, 520-528 (In Persian). 